\title{
Evaluation of Adding Ginger Oil on Sorption and Solubility of Soft Liners Using Different Saliva PH Levels
} Hawraa Khalid Aziz

B.D.S, M.Sc. - Assistant professor, Dental Technologies Department, College of Health and Medical Technology , MTU.

\begin{abstract}
Background: Soft lining denture base materials have a key role in modern prosthodontics, but the major problem with soft linings is that they show change in the sorption and solubility after being used for a long period, which lead to dramatically effect on the dimensional stability and on the adhesion of soft lining acrylic denture base material. The purpose of this study was to investigate the effect of adding plant oil extracts on sorption and solubility of soft linings as well as the effect of different $\mathrm{pH}$ levels of artificial saliva at different times of immersion on sorption and solubility of soft linings.

Materials and methods: 270 specimens were made from heat cured soft liner materials and divided into three groups (90 specimens in each group) according to the addition of ginger oil extracts. The first group was the control group made of soft liners only without adding ginger oil; we added $2 \%$ of ginger oil extract to the second group and $5 \%$ to the third group. Each group was divided into subgroups according to the immersion time of different $\mathrm{pH}$ artificial saliva levels (neutral, basic and acidic). There were three different periods of immersion: 1week, 3 weeks and 6 weeks. The sorption and solubility of each specimen were measured separately.

Results: The results showed that there was no significant difference in the sorption and solubility of soft linings when adding plant oil extracts, but there was a highly significant difference when different $\mathrm{pH}$ levels of artificial saliva were used. The result also showed a highly significant difference when we used different times of immersion.

Conclusion: The findings of the study concluded that there was no effect on the sorption and solubility of the soft liners when adding plant oil extracts and there was a highly significant difference on the sorption and solubility of soft lining materials when immersed in different $\mathrm{pH}$ levels of artificial saliva at different periods.
\end{abstract}

KEY WORDS:

ginger oil, sorption, solubility, $\mathrm{pH}$ of saliva

CITE THIS ARTCLE:

Aziz H. Evaluation of Adding Ginger Oil on Sorption and Solubility of Soft Liners Using Different Saliva PH Levels . Iraqi Dent. J. 2015; 37(2):43-50. http://www.iraqidentaljournal.com

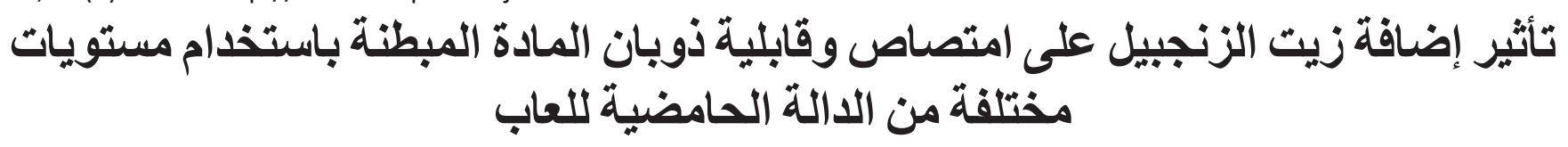

$$
\text { استاذ مساعد , قسم تقنيات الاسنان , كلية التقنيات الصحية و الطبية , الجامعة التقنية الوسطى }
$$

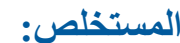

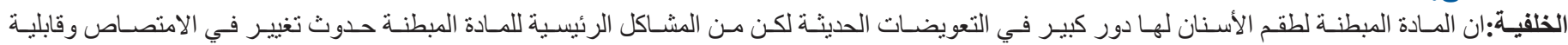

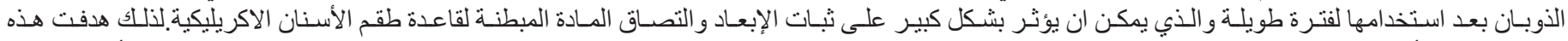

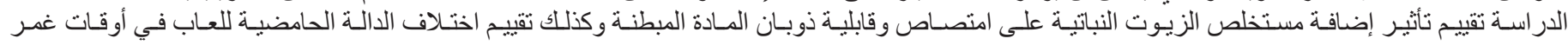

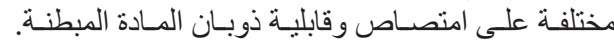

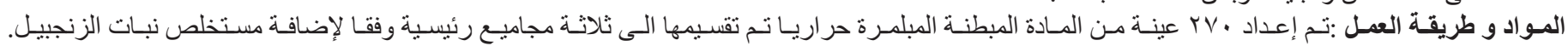

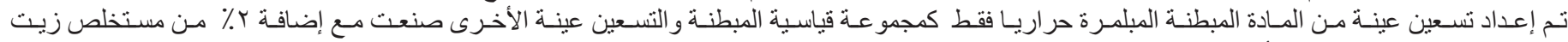

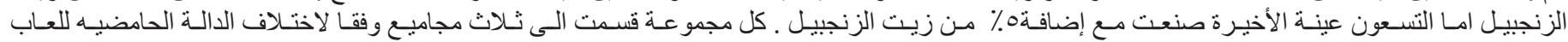

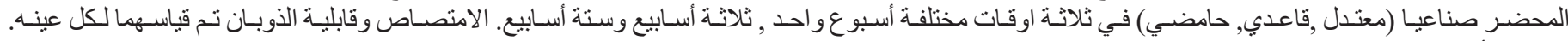

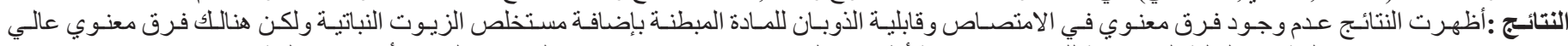

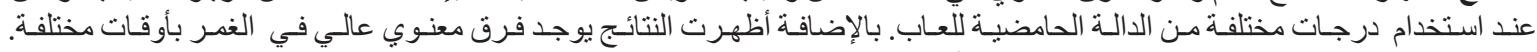

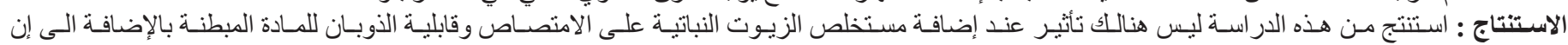

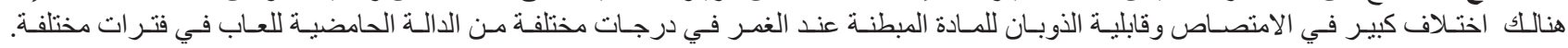

\section{INTRODUCTION}

Denture lining materials have become important in dental prosthetic treatment. They are applied to the intaglio surface of dentures to achieve more equal force distribution, reduce localized pressure, and improve denture retention by engaging undercuts ${ }^{(1)}$. Therefore, soft liners are used to evenly distribute the forces applied to soft tissues during function ${ }^{(2)}$. They are also used when a patient cannot tolerate the hard denture base and to improve retention of an ill-fitting denture. During the use soft liners, the materials are in continuous contact with saliva and during storage they are soaked in water or an aqueous cleaning solution. During such contact, the soft liner materials undergo two responses: the plasticizers and other soluble components are leached out and water or saliva is 
absorbed inside voids, which favor the colonization of yeasts and Candida ${ }^{(3)}$ and cause the denture stomatitis, which is the most common infectious disease affecting the palatal mucosa ${ }^{(4,5)}$. In recent years, there has been an increasing interest in the use of natural substances, essential concentrated oils, and hydrophobic liquids extracted from plants. They possess a wide spectrum of pharmacological activities. The antimicrobial effects of essential oils have been documented and used in herbal medicine in many countries ${ }^{(6)}$. The use of natural products as disinfectants or denture cleansers is greatly advantageous over using systemic approach by antibiotics or local approach with synthetic products or some oral antibiotics including safety and biocompatibility. Natural products have no chance to develop bacterial resistance ${ }^{(7)}$. They are effective as fungicidal and bactericidal agents, have anti-tumor, anti-oxidant, antiinflammatory, anti-bacterial activity and stimulate the immune system ${ }^{(8)}$, in addition to their low cost and availability in mostly every house. Recently, many researchers have verified that essential natural oils have antifungal, antiviral, antibacterial and antiamoebic actions, including nigella (nigella sativa), sesame (Sesamumindicum), flax (Linumusitatissimum) and ginger oil (Zingiberofficinale) ${ }^{(9)}$, and some of these oils are safe and biocompatible materials ${ }^{(10)}$. Zingiberofficinale is one of the most widely used species of the ginger family. It has a long history of medicinal use dating back to 2500 years in China and India. Recently, medical researchers have also verified that ginger contains several bioactive constituents and possesses health-promoting properties ${ }^{(11)}$. Antifungal activity of ginger extracts observed by a study done by Zahra et al showed a significant effect on the oral species of Candida albicans ${ }^{(12)}$.

One the other hand, the aging process could also affect the properties of the denture while in use due to rigorous clinical conditions such as alteration in $\mathrm{pH}$, salivary flow and temperature ${ }^{(13)}$. The $\mathrm{pH}$ of saliva could be more acidic due to certain types of food like orange juice, sugar, candy, pastries, smoking or diseases such as Sjögren's syndrome and chemotherapy, which could cause the saliva to be acidic. Saliva $\mathrm{pH}$ could be more alkaline due to food like amaranth or due to disease like a problem in digestive functions, including enzyme production and pancreas secretions and eliminative functions, especially the liver and lymphatic system ${ }^{(14)}$. One of the common problems of soft denture liners is water sorption and solubility ${ }^{(15)}$. This problem is associated with changes in the structure and physical properties of the materials and their dimensional stability that result in swelling, distortion, color changes, support of Candida albicans growth and stresses at the liner denture base interface that reduce bond strength ${ }^{(3)}$.

The aim of the present study was to investigate the effect of adding ginger oil and the effect of different $\mathrm{pH}$ levels of artificial saliva for different immersion periods on the sorption and solubility of the heat cured soft lining materials.

\section{MATERIALS AND METHODS}

The 270 specimens were prepared from permanent heat cure soft denture lining materials (Vertex ${ }^{\mathrm{TM}}$ Soft, Vertex-Dental, Netherlands) in three major groups according to the addition of plant oil extract:

- Group I: specimens made from soft liner only (the control group)

- Group II: specimens made form soft liner with $2 \%$ of ginger oil (Hemani, Pakistan)

- Group III: specimens made form soft liner with 5\% of ginger oil (Hemani, Pakistan)

For each major group the specimens were classified according to the $\mathrm{pH}$ of the artificial saliva, as follows:

- Group a: specimens immersed in neutral artificial saliva at $\mathrm{pH} 7$.

- Group b: specimens immersed in basic artificial saliva at $\mathrm{pH} 8.3$.

- Group c: specimens immersed in acidic artificial saliva at $\mathrm{pH} 5.7$.

The specimens were divided into 3 subgroups according to the time of immersion: 1week, 3 weeks and 6 weeks.

\section{Specimens preparation}

The specimens were prepared by using a stainless steel disc with dimensions of $50 \mathrm{~mm} \pm 1 \mathrm{~mm}$ diameter and $0.5 \mathrm{~mm} \pm 0.1 \mathrm{~mm}$ thickness for soft liner materials, following the ADA specifications No.12 (1999) ${ }^{(16)}$. The vertex soft lining material which was supplied as powder and liquid was placed into the prepared mould, according to the manufacturer's instructions $(12 \mathrm{~g}: 10 \mathrm{ml})(\mathrm{p} / \mathrm{l})$ and applied into the mould by a spatula. The flask was closed and pressure was applied by using a hydraulic press up to $100 \mathrm{Kpa}$ for 10 minutes, the pressure was then released and the flask was transferred into thermostatically controlled water bath to polymerize, and the cold water was then heated slowly at $70^{\circ} \mathrm{c}$ for an hour and a half, the temperature was then raised to $100{ }^{\circ} \mathrm{C}$ for one hour and a half, then it was removed; and allowed to cool 
slowly before opening it;. After opening, the excess was cut with a sharp knife then the specimen was removed from the mould slowly. For the groups with the addition of ginger oil to the soft liner, the ginger oil was used as an additive to the acrylic and subtracted its volume into $2 \%$ and $5 \%{ }^{(17,18)}$. The samples were packed directly into the prepared mould and then placed to be cured according to the manufacturer's instructions as the control group.

We prepared the artificial saliva with an electronic balance and $\mathrm{PH}$ meter in three different pH levels: 7, 8.3, and 5.7.An electrolyte composition similar to that of human saliva was used in the study (19) including:

$\begin{array}{ll}\text { - Na2HPO4 } & 0.260 \mathrm{~g} / \mathrm{I} \\ \text { - NACL } & 0.700 \mathrm{~g} / \mathrm{I} \\ \text { - KSCN } & 0.330 \mathrm{~g} / \mathrm{I} \\ \text { - KH2PO4 } & 0.200 \mathrm{~g} / \mathrm{I} \\ \text { - NaHCO3 } & 1.500 \mathrm{~g} / \mathrm{I} \\ \text { - KCL } & 1.200 \mathrm{~g} / \mathrm{I}\end{array}$

The artificial saliva was prepared in three different $\mathrm{pH}$ levels (neutral, base and acid). Buffer solution was first prepared from $\mathrm{KH} 2 \mathrm{PO} 4$ and $\mathrm{Na} 2 \mathrm{HPO} 4$ by dissolving each salt in 1 liter of de-ionized distilled water.

The neutral saliva solution was prepared as in the previous manner, but the amount of Na2HPO4 solution was gradually added until it reached $\mathrm{pH} 7$ as it was recorded by the digital $\mathrm{pH}$ meter placed in the flask.

The basic saliva $(8.3 \pm 0.01)$ was prepared by placing $500 \mathrm{ml}$ of Na2HPO4 in a graduated flask and $\mathrm{KH} 2 \mathrm{PO} 4$ solution was gradually added until it reached the required $\mathrm{pH}$, then the remaining salts of artificial saliva were added and the volume was completed to 1 liter by de-ionized distilled water.

The acidic solution $(5.7 \pm 0.01)$ was prepared by placing $500 \mathrm{ml}$ of $\mathrm{KH} 2 \mathrm{PO} 4$ in a graduated flask and Na2HPO4 solution was added gradually until it reached the required $\mathrm{pH}$, then the remaining salts of artificial saliva were added and the volume was completed to 1 liter by distilled water. All the samples were stored in artificial saliva inside the incubator at $37{ }^{\circ} \mathrm{C}$ for different periods of immersion: 1 week, 3 weeks and 6 weeks. The artificial saliva was changed every day because the $\mathrm{pH}$ of saliva changed within 48 hours ${ }^{(13)}$

\section{Water sorption and water solubility test}

The specimens were dried in a desiccator containing freshly dried silica gel arranged according to their group and separated by filter paper. The desiccator was then stored in an incubator at $37^{\circ} \mathrm{C}$ for 24 hours. The specimens were removed to a similar desiccator at room temperature for one hour then weighed with a digital balance with a precision of $0.2 \mathrm{mg}$. This cycle was repeated until a constant mass (W1) was reached (the weight loss of each disc was not more than $0.5 \mathrm{mg}$ in 24 hours). The discs were then labeled according to their specific subgroups as described previously. The discs for the test groups were then immersed in a $250 \mathrm{ml}$ of artificial saliva at $37{ }^{\circ} \mathrm{C}$ in a closed polyethylene containers for 1week, 3 weeks and 6 weeks, respectively. For all test groups, the discs were removed from distilled water with tweezers and wiped with a clean dry towel until they were free of moisture, waved in the air for 15 seconds and weighed one minute after removal from the water, and this mass was recorded as (W2). To obtain the value of solubility test, the discs were reconditioned to a constant mass in the desiccators at $37^{\circ} \mathrm{C}$ as done previously for the sorption test and the constant reconditioned mass was recorded as (W3). The values for sorption and solubility tests were calculated for each disc using the following equation and the final value was rounded to the nearest $0.1 \mathrm{mg} /$ $\mathrm{cm}$ :

$$
\text { - } \operatorname{sorption}\left(\mathrm{mg} / \mathrm{cm}^{2}\right)=\frac{W_{2}-W_{1}}{\text { surfacearea }}
$$

- solubility $\left(\mathrm{mg} / \mathrm{cm}^{2}\right)=\frac{W_{1}-W_{3}}{\text { surfacearea }}$

The specimen preparation and testing procedure were done according to ADA specification NO. 12 for denture base resin.

\section{Statistical analysis}

The data was statistically analyzed with the computer program Statistical Package for Social Sciences (SPSS) version 15.0 for Windows. The means and standard deviations were obtained. Oneway analysis of variance (ANOVA) was used to compare the control groups and the groups of addition of $2 \%$ and $5 \%$ of ginger oil for different periods, and for comparison of immersion in different $\mathrm{pH}$ of artificial saliva. A 95\% confidence levels were used.

\section{RESULTS}

\section{Water sorption and solubility test}

Descriptive statistics of the results of sorption and solubility values of the heat-cured soft liners for the control group showed the highest mean values, while the addition of the plant oil extracts $2 \%$ and $5 \%$ of ginger oil showed the lowest mean values. 
The sorption and solubility results of the soft liners highest mean values for the specimens immersed revealed that the lowest mean values for the specimens in acidic saliva in general as shown in (Table1) and immersed in neutral saliva than basic saliva and the (Figure1).

Table (1): Mean and standard deviation values of sorption and solubility of the soft liner for all groups (1 week, 3 weeks, and 3 weeks).

\begin{tabular}{|c|c|c|c|c|c|c|c|c|c|c|c|c|c|}
\hline & \multicolumn{6}{|c|}{ Sorption } & \multicolumn{6}{|c|}{ Solubility } \\
\hline & & \multicolumn{2}{|c|}{$\begin{array}{c}\text { Group I } \\
0 \% \text { ginger oil }\end{array}$} & \multicolumn{2}{|c|}{$\begin{array}{c}\text { Group II } \\
2 \% \text { ginger oil }\end{array}$} & \multicolumn{2}{|c|}{$\begin{array}{l}\text { Group III } \\
5 \% \text { ginger oil }\end{array}$} & \multicolumn{2}{|c|}{$\begin{array}{l}\text { Group I } \\
\text { 0\% ginger } \\
\quad \text { oil }\end{array}$} & \multicolumn{2}{|c|}{$\begin{array}{l}\text { Group II } \\
2 \% \text { ginger } \\
\quad \text { oil }\end{array}$} & \multicolumn{2}{|c|}{$\begin{array}{l}\text { Group III } \\
5 \% \text { ginger } \\
\text { oil }\end{array}$} \\
\hline & & Mean & SD & Mean & SD & Mean & SD & Mean & SD & Mean & SD & Mean & SD \\
\hline \multirow{3}{*}{$\begin{array}{c}1 \\
\text { week }\end{array}$} & $\begin{array}{c}\text { Group a1 } \\
\text { (Neutral } \mathrm{pH} \text { ) }\end{array}$ & 0.3205 & 0.146 & 0.3103 & 0.116 & 0.3060 & 0.084 & 0.2292 & 0.15 & 0.1811 & 0.04 & 0.1525 & 0.07 \\
\hline & $\begin{array}{l}\text { Group b } 1 \\
\text { (Basic pH) }\end{array}$ & 0.4646 & 0.089 & 0.4339 & 0.074 & 0.3966 & 0.057 & 0.2655 & 0.13 & 0.2000 & 0.12 & 0.1714 & 0.15 \\
\hline & $\begin{array}{c}\text { Group c } 1 \\
\text { (Acidic pH) }\end{array}$ & 0.5725 & 0.150 & 0.5073 & 0.089 & 0.5507 & 0.143 & 0.4446 & 0.04 & 0.395 & 0.08 & 0.3659 & 0.10 \\
\hline \multirow{3}{*}{$\begin{array}{c}3 \\
\text { weeks }\end{array}$} & $\begin{array}{c}\text { Group a } 2 \\
\text { (Neutral pH) }\end{array}$ & 0.5181 & 0.127 & 0.5038 & 0.106 & 0.4845 & 0.137 & 0.3113 & 0.07 & 0.2770 & 0.04 & 0.2480 & 0.04 \\
\hline & $\begin{array}{l}\text { Group b } 2 \\
\text { (Basic pH) }\end{array}$ & 0.5591 & 0.227 & 0.5448 & 0.207 & 0.5360 & 0.020 & 0.3613 & 0.06 & 0.3860 & 0.15 & 0.3575 & 0.17 \\
\hline & $\begin{array}{c}\text { Group c } 2 \\
\text { (Acidic pH) }\end{array}$ & 0.7740 & 0.116 & 0.7454 & 0.114 & 0.6764 & 0.182 & 0.6777 & 0.29 & 0.5830 & 0.14 & 0.5546 & 0.17 \\
\hline \multirow{3}{*}{$\begin{array}{c}6 \\
\text { weeks }\end{array}$} & $\begin{array}{c}\text { Group a3 } \\
\text { (Neutral } \mathrm{pH} \text { ) }\end{array}$ & 0.5038 & 0.106 & 0.5324 & 0.086 & 0.4988 & 0.098 & 0.3390 & 0.03 & 0.3055 & 0.04 & 0.2770 & 0.07 \\
\hline & $\begin{array}{l}\text { Group b } 3 \\
\text { (Basic pH) }\end{array}$ & 0.7448 & 0.132 & 0.6877 & 0.148 & 0.5788 & 0.066 & 0.4470 & 0.08 & 0.4140 & 0.12 & 0.3860 & 0.14 \\
\hline & $\begin{array}{c}\text { Group c } 3 \\
\text { (Acidic pH) }\end{array}$ & 0.7740 & 0.097 & 0.8028 & 0.063 & 0.8050 & 0.092 & 0.7630 & 0.24 & 0.6117 & 0.11 & 0.5830 & 0.14 \\
\hline
\end{tabular}

Figure (1): Bar chart showed: A. the sorption of the soft liner in all groups. B. the solubility of the soft liner in all groups

Effect of the addition of the plant oil extract:In comparison with the mean values of the sorption and solubility of the soft liners according to the addition of ginger oil, the ANOVA test showed there was no significant difference between the test groups as shown in (Table 2).

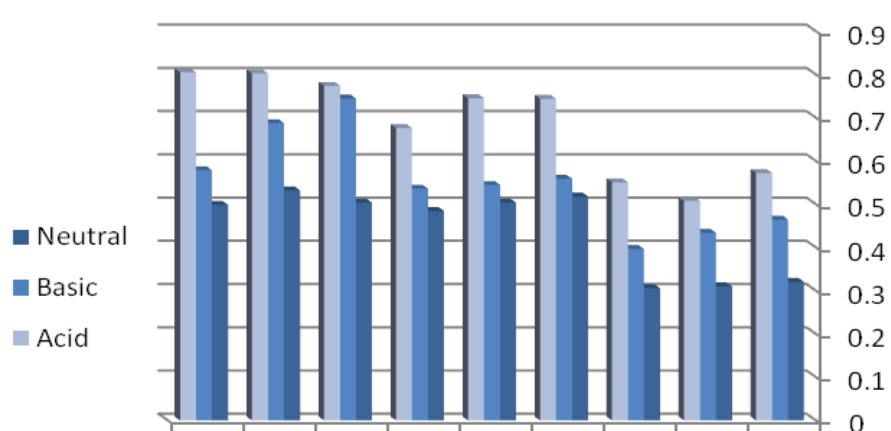

A

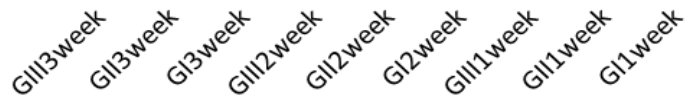

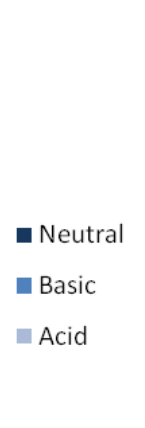

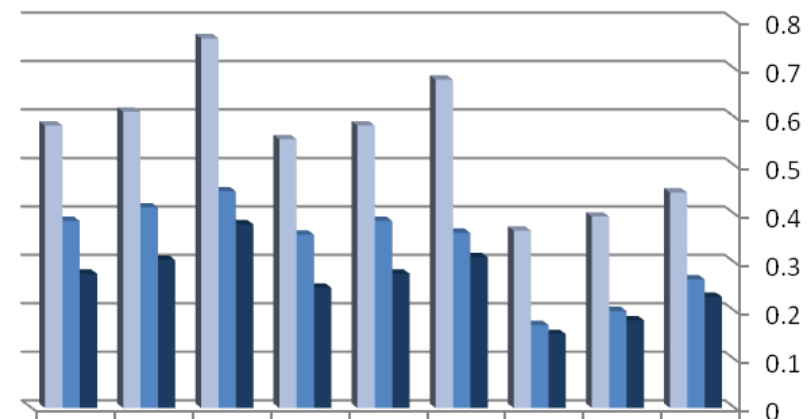

B

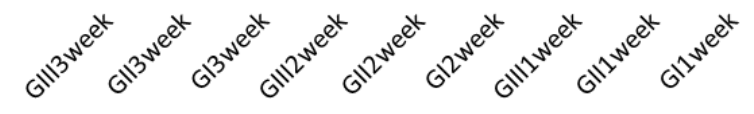

Figure(1): Bar chart showed: A. the sorption of the soft liner in all groups. B. the solubility of the soft liner in all groups

\section{Effect of the addition of the plant oil extract:}

In comparison of means values of the sorption and solubility of the soft liner the ANOVA test was showed there were non significant different between the test groups as shown in ( Table 2). 
Table (2): ANOVA between groups of sorption and solubility of the soft liner according to the addition of the plant oil extracts .

\begin{tabular}{|l|l|l|l|l|l|l|}
\hline & \multicolumn{3}{|c|}{ Sorption } & & Solubility \\
\hline & F-test & p-value & Sig & F-test & p-value & Sig \\
\hline G I a1 \& G II a1 \& G III a1 & 0.028 & 0.973 & NS & 0.950 & 0.405 \\
\hline G I b1 \& G II b1 \& G III b1 & 1.461 & 0.258 & NS & 0.864 & 0.438 \\
\hline G I c1 \& G II c1 \& G III c1 & 0.453 & 0.643 & NS & 1.635 & 0.223 & NS \\
\hline G I a2 \& G II a2 \& G III a2 & 1.28 & 0.880 & NS & 2.145 & 0.146 \\
\hline G I b2 \& G II b2 \& G III b2 & 0.030 & 0.970 & NS & 0.088 & 0.916 \\
\hline G I c2 \& G II c2 \& G III c2 & 0.888 & 0.429 & NS & 0.612 & 0.553 \\
\hline G I a3 \& G II a3 \& G III a3 & 0.242 & 0.788 & NS & 2.527 & 0.108 \\
\hline G I b3 \& G II b3 \& G III b3 & 3.386 & 0.056 & NS & 0.443 & 0.649 \\
\hline G I c3 \& G II c3 \& G III c3 & 0.286 & 0.755 & NS & 2.055 & 0.157 \\
\hline
\end{tabular}

\section{Effect of the different pH levels of saliva}

For the comparison of mean values of the sorption, the ANOVA test indicated that there were highly significant differences between the groups of immersion for 1 week and 6 weeks, while there was a significant difference in the group immersed for 3 weeks and the results of the solubility of different $\mathrm{pH}$ of artificial saliva showed that there were highly significant differences in all groups as shown in (Table $3)$.

The results of the LSD test of the sorption groups showed a non-significant difference between neutral $\mathrm{pH}$ and basic $\mathrm{pH}$ groups except in the control group, but there was a highly significant difference in the groups of $2 \%$ of ginger oil for 6 weeks as well as between the neutral $\mathrm{pH}$ and acidic $\mathrm{pH}$ groups. There was a non-significant difference between groups of basic $\mathrm{pH}$ and acidic $\mathrm{pH}$ except in the group of $2 \%$ of ginger oil group for 3 weeks and the groups for 6 weeks. For solubility test, the results showed a non-significant difference between neutral $\mathrm{pH}$ and basic $\mathrm{pH}$ groups, but a highly significant between the neutral $\mathrm{pH}$ and acidic $\mathrm{pH}$ groups and there was a nonsignificant difference between groups of basic $\mathrm{pH}$ and acidic $\mathrm{pH}$ as shown in (Table 4).

Table (3): ANOVA between groups according to different pH of saliva groups.

\begin{tabular}{|l|c|c|c|c|c|c|}
\hline & \multicolumn{3}{|c|}{ Sorption } & \multicolumn{3}{c|}{ Solubility } \\
\cline { 2 - 7 } & F-test & P-value & Sig & F-test & P-value & Sig \\
\hline GIa1 \& GIb1\& GIc1 & 6.452 & 0.008 & HS & 6.152 & 0.009 & HS \\
\hline GIIa1 \& GIIb1\& GIIc1 & 7.656 & 0.004 & HS & 11.997 & 0.000 & HS \\
\hline GIIIa1 \& GIIIb1\& GIIIc1 & 10.468 & 0.001 & HS & 7.262 & 0.005 & HS \\
\hline GIa2 \& GIb2\& GIc2 & 4.853 & 0.020 & S & 8.417 & 0.003 & HS \\
\hline GIIa2 \& GIIb2\& GIIc2 & 5.204 & 0.016 & S & 10.465 & .001 & HS \\
\hline GIIIa2 \& GIIIb2\& GIIIc2 & 3.966 & 0.037 & S & 8.005 & 0.003 & HS \\
\hline GIa3 \& GIb3\& GIc3 & 12.028 & 0.000 & HS & 11.485 & 0.001 & HS \\
\hline GIIa3 \& GIIb3\& GIIc3 & 11.500 & 0.001 & HS & 15.680 & 0.000 & HS \\
\hline GIIIa3 \& GIIIb3\& GIIIc3 & 23.460 & 0.000 & HS & 10.760 & 0.001 & HS
\end{tabular}

$* \mathbf{P}<0.01$ Highly Significant $\quad * * \mathbf{P}<0.05$ Significant 


\section{Prosithodontics}

Table (4): LSD test between the groups of different pH of saliva groups.

\begin{tabular}{|c|c|c|c|c|c|c|c|c|c|c|c|c|}
\hline \multirow{3}{*}{ Between groups } & \multicolumn{4}{|c|}{ Iweek } & \multicolumn{4}{|c|}{3 weeks } & \multicolumn{4}{|c|}{6 weeks } \\
\hline & \multicolumn{2}{|c|}{ Sorption } & \multicolumn{2}{|c|}{ Solubility } & \multicolumn{2}{|c|}{ Sorption } & \multicolumn{2}{|c|}{ Solubility } & \multicolumn{2}{|c|}{ Sorption } & \multicolumn{2}{|c|}{ Solubility } \\
\hline & P-value & Sig & P-value & Sig & P-value & Sig & P-value & Sig & P-value & Sig & P-value & Sig \\
\hline Group I a \& Group Ib & 0.056 & NS & 0.588 & NS & 0.475 & NS & 0.612 & NS & 0.001 & HS & 0.554 & NS \\
\hline Group I a \& Group Ic & 0.002 & HS & 0.004 & HS & 0.014 & $\mathrm{~S}$ & 0.001 & HS & 0.000 & HS & 0.000 & HS \\
\hline Group I b \& Group Ic & 0.143 & NS & 0.014 & HS & 0.062 & NS & 0.004 & HS & 0.636 & NS & 0.001 & $\mathrm{HS}$ \\
\hline Group II a \& Group IIb & 0.060 & NS & 0.700 & NS & 0.615 & NS & 0.125 & NS & 0.013 & S & 0.065 & NS \\
\hline Group II a \& Group IIc & 0.001 & HS & 0.000 & HS & 0.007 & HS & 0.000 & HS & 0.000 & HS & 0.000 & $\mathrm{HS}$ \\
\hline Group II b \&Group IIc & 0.166 & NS & 0.001 & HS & 0.022 & $\mathrm{~S}$ & 0.009 & HS & 0.057 & NS & 0.002 & HS \\
\hline Group III a\&Group IIIb & 0.111 & NS & 0.764 & NS & 0.647 & NS & 0.177 & NS & 0.102 & NS & 0.120 & NS \\
\hline Group III a\&Group IIIc & 0.000 & HS & 0.003 & HS & 0.009 & HS & 0.001 & HS & 0.000 & HS & 0.000 & HS \\
\hline Group III b\&Group IIIc & 0.011 & $\mathrm{~S}$ & 0.006 & HS & 0.025 & $\mathrm{~S}$ & 0.021 & $\mathrm{~S}$ & 0.000 & HS & 0.009 & HS \\
\hline
\end{tabular}

\section{Effect of the time of immersion}

In comparison of mean values of the sorption and solubility of the soft liners at different times of immersion for 1 week, 3 weeks and 6 weeks. The ANOVA test showed there were significant and highly significant differences between the tested groups as shown in (Table 5). The LSD test between groups of sorption test showed a highly significant difference between the groups of immersion for 1 week and 3 weeks as well as between 1 week and 6 weeks groups except in the control group and the group of $2 \%$ of ginger oil where the results showed there was no significant difference between immersion basic $\mathrm{pH}$ for 1 week and 3 weeks groups, also there was non significant between immersion for 3 weeks and 6 weeks in all groups. For solubility test, the result showed a highly significant difference between the immersion for 1 week and 3 weeks groups and immersion for 1 week and 6 weeks. There were no significant differences in the control group and between groups of immersion for 3 weeks and 6 weeks as shown in (Table 6)..

Table(5): ANOVA between groups of the soft liners according to time of immersion.

\begin{tabular}{|c|c|c|c|c|c|c|}
\hline & \multicolumn{3}{|c|}{ Sorption } & \multicolumn{3}{c|}{ Solubility } \\
\hline & F-test & p-value & Sig & F-test & p-value & Sig \\
\hline G I a1 \& G I a2 \& G I a3 & 5.188 & 0.017 & S & 4.266 & 0.030 & S \\
\hline G I b1 \& G I b2 \& G I b3 & 5.523 & 0.013 & S & 5.884 & 0.011 & S \\
\hline G I c1 \& G I c2 \& GI c3 & 6.244 & 0.009 & HS & 3.764 & 0.043 & S \\
\hline G II a1 \& G II a2 \& G II a3 & 9.444 & 0.002 & HS & 13.946 & 0.000 & HS \\
\hline G II b1 \& G II b2 \& G II b3 & 4.811 & 0.021 & S & 4.996 & 0.019 & S \\
\hline G II c1 \& G II c2 \& G II c3 & 20.522 & 0.000 & HS & 7.052 & 0.005 & HS \\
\hline G III a1 \& G III a2 \& G III a3 & 6.815 & 0.006 & HS & 6.745 & 0.007 & HS \\
\hline G III b1 \& G III b2 \& G III b3 & 23.799 & 0.000 & HS & 3.977 & 0.037 & S \\
\hline G III c1 \& G III c2 \& G III c3 & 5.481 & 0.014 & S & 4.463 & 0.027 & S \\
\hline
\end{tabular}

* $\mathbf{P}<0.05$ significant $\quad * * \mathbf{P}<0.01$ highly significant 
Table (6): LSD test between the groups of different time of immersion.

\begin{tabular}{|c|c|c|c|c|}
\hline \multirow{3}{*}{ Between groups } & \multicolumn{4}{|c|}{ Group I } \\
\hline & \multicolumn{2}{|c|}{ Sorption } & \multicolumn{2}{|c|}{ Solubility } \\
\hline & $\begin{array}{c}\text { P-val- } \\
\text { ue }\end{array}$ & Sig & $\begin{array}{c}\text { P-val- } \\
\text { ue }\end{array}$ & Sig \\
\hline Groupa1 \& Group a2 & 0.010 & HS & 0.170 & NS \\
\hline Group a1 \& Group a3 & 0.015 & $\mathrm{~S}$ & 0.009 & HS \\
\hline Group a 2 \& Group a3 & 0.837 & NS & 0.153 & NS \\
\hline Group b1 \& Group b2 & 0.285 & NS & 0.087 & NS \\
\hline Group b1 \& Group b3 & 0.004 & HS & 0.003 & HS \\
\hline Group b2 \& Group b3 & 0.044 & S & 0.123 & NS \\
\hline Group c1 \& Group c2 & 0.007 & HS & 0.068 & NS \\
\hline Group c1 \& Group c3 & 0.007 & HS & 0.016 & $\mathrm{~S}$ \\
\hline Group c2 \& Group c3 & 1.000 & NS & 0.485 & NS \\
\hline
\end{tabular}

\begin{tabular}{|c|c|c|c|c|c|c|c|}
\hline \multicolumn{3}{|c|}{ Group II } & \multicolumn{4}{|c|}{ Group III } \\
\hline \begin{tabular}{c} 
Sorption \\
\hline $\begin{array}{c}\text { P-val- } \\
\text { ue }\end{array}$
\end{tabular} & $\begin{array}{c}\text { Sig } \\
\text { Solubility }\end{array}$ & $\begin{array}{c}\text { Sorption } \\
\text { ue }\end{array}$ & Sig & $\begin{array}{c}\text { P-val- } \\
\text { ue }\end{array}$ & Sig & $\begin{array}{c}\text { Solubility } \\
\text { ue }\end{array}$ & Sig \\
\hline 0.003 & HS & 0.001 & HS & 0.007 & HS & 0.015 & S \\
\hline 0.001 & HS & 0.000 & HS & 0.004 & HS & 0.003 & HS \\
\hline 0.614 & NS & 0.262 & NS & 0.809 & NS & 0.431 & NS \\
\hline 0.193 & NS & 0.021 & S & 0.000 & HS & 0.037 & S \\
\hline 0.006 & HS & 0.009 & HS & 0.000 & HS & 0.018 & S \\
\hline 0.099 & NS & 0.703 & NS & 0.138 & NS & 0.734 & NS \\
\hline 0.000 & HS & 0.008 & HS & 0.119 & NS & 0.028 & S \\
\hline 0.000 & HS & 0.003 & HS & 0.004 & HS & 0.013 & S \\
\hline 0.256 & NS & 0.655 & NS & 0.111 & NS & 0.722 & NS \\
\hline
\end{tabular}

\section{DISCUSION}

Soft lining materials have been used in dentistry for more than a century. These materials play an important role in modern prosthodontics. Many of these materials have been used with varying levels of success, but limitations exist including water sorption and solubility that cause dimensional instability, thus subjecting the materials to internal stress that results in crack formation and fracture of the denture (20). Therefore, the desirable objective of soft liner materials is low sorption and stability to prevent the problem of adhesion to the under lining acrylic denture base.The water sorption of material represents the amount of water absorption on the surface and to the body of material while any observed loss of weight of material is a measure of the solubility (21).

The tested samples of soft liner materials for all groups fulfilled the requirements regarding sorption within the range $\left(0.2-5.6 \mathrm{mg} / \mathrm{cm}^{2}\right)^{21}$.

\section{Effect of the addition of plant oil extracts}

The natural medicinal plants are still a major source of therapeutic agents for infectious diseases (22). The results showed that the sorption and solubility of soft liners with the addition of ginger oil decreased mean values in comparison with the control group, but statistically there were no significant differences. This may be due to the addition of ginger oil into soft liners, which reduces porosity, the sorption and the solubility, and produce dense and heavier specimens that lead to less micro pockets of water ${ }^{(23)}$. On the other hand, the natural products of plant oil extracts showed an unmatched of chemical diversity ${ }^{(24)}$. This agrees with ${ }^{(25)}$, who concluded that the use of oil as additive to reduce adherence of Candida albicans without significantly affecting some properties and adhesion to heat polymerized resin.

\section{Effect of different pH levels of saliva}

The results of this study showed there were no significant differences between the immersion in neutral saliva and basic saliva regarding the sorption and solubility of soft liners, but there was a significant difference in sorption and solubility when immersed in acidic saliva; this may be due to erosion effect of acidic median or due to cationic reaction ${ }^{(26)}$. This may cause weight changes that cause differences between initial dry weight and saturated weight ${ }^{(3)}$.

The sorption and solubility of soft liner did not change in the neutral and basic artificial saliva this could be explained by the fact that the water sorption and solubility depended on the resin composition and the time necessary to saturate or dry out an appliance and the temperature that affected the diffusion of water but had no effect on the equilibrium water content. Therefore, the sorption and solubility of soft liners did not change in neutral or basic artificial saliva ${ }^{(27)}$.

\section{Effect of time of immersion}

The results of this study showed that there were highly significant differences between 1 week and 3 weeks of immersion in artificial saliva and for 1 week and 6 weeks. This might be due to the gabs in polymer chains that led to different liquids such as artificial saliva or distilled water which can penetrate and cause the change in the mechanical properties of the polymer ${ }^{(28)}$. For the control group and the group of $2 \%$ of ginger oil the, results showed there was no difference in the sorption, which may be attributed to the high cross-linking nature of the materials. The 
heat process of curing which involves the application of pressure may create denser material so that the micro pockets of water may exist within the material and it takes longer time to be saturated because of difficulty of water to be absorbed in this material; therefore, the material was little affected by the time of artificial saliva storage ${ }^{(3)}$. The result is in agreement with ${ }^{(28)}$, who concluded that soft liners revealed a highly significant increase regarding time of storage for 1 week, 3 weeks, or 1 week and 6 weeks, but there was no difference between immersion in 3 weeks and 6 weeks on sorption and solubility of different soft lining materials.

\section{CONCLUSION}

The findings of this study concluded that there was no effect on the sorption and solubility of soft liners when adding plant oil extracts, but there was a significant difference in the sorption and solubility of soft lining materials when immersed in different $\mathrm{pH}$ levels of artificial saliva for different periods.

\section{REFERENCES}

1. Mese A, Guzel KG. Effect of storage duration on the hardness and tensile bond strength of silicone-and acrylic resin-based resilient denture liners to a processed denture base acrylic resin.J Prosthet Dent 2008;99(2):153-159.

2. Multuay MM, Ruyter LE. Evaluation of bond strength of soft relining materials to denture base polymers. Dental Materials 2007; 23:1373-81.

3. El-Hadary A,Drummond JL.Comparative study of water, Solubility, and tensile bond strength of two soft lining materials. Prosthet Dent 2000, 83(3), 356-361.

4. Dhir G, Berzins DW, Dhuru VB, Peria-thamby AR, Dentino A: Physical proper-ties of denture base resins potentially resistant to Candida adhesion.J Prosthodont2007;16(6):465-72.

5. Karaagaclioglu L, Can G, Yilmaz B, Ayhan N, Semiz O, Levent H: The adherence of Candida albicans to acrylic resin reinforced with different fibers. J Mat Sci: Mat in Med. 2008; 19(2):959-63.

6. Hamedo HA.Monitoring of Antimicrobial Activity of Essential Oils Using Molecular Markers 2009;Open Biotechnol J:103-107.

7. Linke HA, Meeker HG. The antibacterial action of eugenol, thyme oil, and related essential oils used in dentistry. New York University, New York 2005 ; pp: 1-5.

8. Cavar S, Maksimovic M, Solic ME, Jerkovic-Mujkic A, Besta R. Chemical composition and antioxidant and antimicrobial activity of two Satureja essential oils. Food Chemistry. 2008; Article in Press.

9. Cheikh-Rouhou S, Besbes S, Hentati B, Bleckera C, Deroanne C, Attia H. Nigella sativa L: Chemical composition and physicochemical characteristics of lipid fraction. Food Chemistry. 2007; 101: 673-681.

10. British Pharmacopoeia: Volume III of the European Pharmacopoeia. 5th ed. 2007.

11. Waggas AM. Neuroprotective evaluation of extract of ginger (Zingiberofficinale) Root in monosodium glutamateinduced toxicity in different brain areas malealbnrats 2009; Pak J Biol Sci;12(3):201-212.

12. Atai Z, Atapourb M, Mohseni M. Inhibitory Effect of Ginger Extracton Candida albicans. Am J Applied Sci 2009; 6(6):1067-1069.

13. Garcia LF, Roselino LM, Mundim FM, Consani S. The influence of artificial accelerated aging on dimensional stability of acrylic resin submitted to different storage protocols. J. Prosthodont 2010; 19:432-37.

14. Minich DM, Bland JS. Acid-alkaline balance: role in chronic disease and detoxification. Alternative Therapies in Health and Medicine 2007; 13: 62-5.

15. Yanikuglu ND, Duymus ZY. Comparative study of soft lining materials in the different solutions . Dent Mater J 2004; 23(2): 233-239.

16. ADA. 1999. American national standers institute/American dental association specification No.12 for denture base polymer. Chicago: council on dental material and device.

17. Sayidmarie HNA, Haim AKH. Evaluation of addition of plant fixed oil extracts (Sesame, Thyme) as antifungal on some properties of a heat cured soft lining material. Abstract of First National Conference For Iraqi Dental Colleges 2012; pp:13.

18. Al-Nema LM. Al-Irhayim RN. Khuder H. Evaluation of Addition of Plant Fixed Oil Extracts (Ginger, Maramia, Eucalyptus) on Some Properties of Heat Cured Denture Base Material. Al-Rafidain Dent J. 2014; 14(1): 132-138.

19. Pusz A, Szymiczek M, Michalik K. Ageing process influence on mechanical properties of polyamide-glass composites applied dentistry. J Achiv. Mat 2010; 38(1) 49-55.

20. Pfeiffer P, Rosen Bauer EU. Residual methyl methacrylate monomer, water sorption and solubility of hypoallergenic denture. J Prosthet dent 2004; 2:72-78.

21. Craig RG, Powers JM, Wataha JC. Dental Materials: Properties and Manipulation . 8th ed. St Louis : Mosby, 2004.

22. Clardy J, Walsh C_Lessons from natural molecules. Nature 2004; pp: 432,829-837.

23. Abdul-Rahmann B.A: Evaluation of water sorption, solubility and bond strength of some soft lining matreial. Master thesis, prosthodontic department, College of dentistry, university of Baghdad, 2002.

24. Jeon JG, Rosalen PL, Falsetta ML. natural products in caries research: current knowledge challenge and future perspective. Caries research 2011;45:243-263.

25. Srivatstava A, Ginjupallik, Perampalli NU, Bhat N. Evaluation of the properties of tissue conditioner containing origanum oil as an antifungal additive. J Prosth Dent 2013,110(4): 313-319.

26. Constantinescue I.R., Ursache M., Mardarez D: Effect of ph on the surface roughness of heat cured denture base acrylic resin. Rev. Med.Chir. Soc Med Nat Iasi.2007; 111(2):47781.

27. Shorouq MA, Rafah AJ, Aseel MA. Effect of immersion in sodium chloride solution during microwave disinfection on dimensional stability, water sorption and water solubility of denture base acrylic resin. J Bagh College Dent 2010; 22(3)46-51.

28. Abdul Sahib AJ. Evaluation of some physical properties of two permanent heat cure silicone soft lining materials. Master thesis, prosthodontic department, college of dentistry, university of Baghdad, 2007. 